\title{
Stereotypy i fantazje. Science fiction i psychologia
}

Jeśli przyjąć, że dyskurs nauk przyrodniczych i wizje światów definiowanych przez fantastyczne wynalazki zdominowały science fiction ${ }^{1}$, zestawianie jej z psychologią wydaje się ryzykowne. Ta obiegowa opinia ma swoje uzasadnienie $\mathrm{w}$ programowym postrzeganiu fantastyki naukowej $\mathrm{z}$ okresu jej krystalizacji, a także w kontekście rewitalizacji tematyczno-retorycznego trzonu „hard" 2. A jednak, wielowymiarowość, bogactwo tematyczne, a przede wszystkim ewolucja tej konwencji, zmierzająca w stronę rozszerzania spekulatywności o nauki społeczne i humanistyczne, pozwalają na poszukiwanie połączeń wbrew obiegowym sądom.

Warto tu wspomnieć, że obecność w literaturze naukowości jako takiej traktowana jest podejrzliwie. Przez akademicką humanistykę najczęściej włączana jest do analizy retoryki fikcji literackiej. Co oczywiste, science fiction źródłem wiedzy naukowej być nie może, a dodatkowo powinno się ją odróżniać od piśmiennictwa popularnonaukowego. Samo więc zestawienie jakiej-

\footnotetext{
1 Antoni Smuszkiewicz oddziela etymologiczne znaczenie terminu science fiction od jego funkcjonowania „w literaturoznawstwie i języku potocznym” [A. Smuszkiewicz, Hasło Science fiction, w: A. Niewiadowski, A. Smuszkiewicz, Leksykon polskiej literatury fantastycznonaukowej, Poznań 1990, s. 346].

2 Tamże, s. 298 (hasło Hard science fiction); K. Cramer, Hard SF, w: The Cambridge Companion to Science Fiction, red. E. James, F. Mendlesohn, Cambridge 2003.
} 
kolwiek dziedziny nauki, przyrodniczej czy humanistycznej, z fikcją literacką obarczone jest ryzykiem. Wprawdzie wielu czytelników zawsze będzie szukać w literaturze fantastycznonaukowej wiedzy, choćby jako autentyczności odniesienia do naukowego materiału, ale innym taka zależność wyobraźni wydać się może ograniczeniem.

Na szczęście ryzyko zestawiania literackiej fantastyki naukowej z psychologią bywa podejmowane, czego przykład stanowi monografia Gavina Millera Science Fiction and Psychology $(2020)^{3}$. Książka Millera aspiruje do rangi wszechstronnej i aktualnej analizy konfrontacji między konwencją fantastycznonaukową a psychologią. Autor, przedstawiający się jako historyk psychologii ${ }^{4}$, zestawia obie te dziedziny zaskoczony ich nieoczywistą bliskością, ale też świadom ryzyka przedsięwzięcia. Miller nie poprzestaje na podstawowym wyliczeniu punktów stycznych obu obszarów ludzkiej aktywności, twórczej i naukowej. Jego ambicje sięgają dalej. Doszukuje się bowiem zależności na głębszych poziomach struktury wiedzy i wyobraźni. Przede wszystkim, jak twierdzi, zbieżność momentów narodzin psychologii i konwencji fantastycznonaukowej nie jest przypadkowa. Obie powstały pod koniec XIX wieku, czyli w czasie, gdy można było zaobserwować wzmożone zainteresowanie ludzką psychiką oraz - równolegle - burzliwy rozwój nauki i techniki. Procesy te łączy - wbrew pozorom - gęsta sieć współzależności.

Ich głównym spoidłem jest "naukowość”. To ona właśnie definiuje zakres sprzężenia, niejednorodny i zmienny - żywy. W obu przypadkach naukowość funkcjonuje jednak inaczej, w różnych kontekstach. Przenikanie koncepcji psychologicznych do fikcji fantastycznej - dość oczywiste - okazuje się zaledwie jednym $\mathrm{z}$ wymiarów tego zjawiska. Zauważyć można odwrotny kierunek oddziaływania, a przede wszystkim - wspólną podstawę. Podstawa ta nie jest jednak do końca statyczna jako współokreślana przez wciąż aktywny mechanizm różnicowania - uświadamianego oddalenia i rozgrywania dystansu między nauką a literaturą, zarówno z perspektywy psychologii, gdy "zaraża się" ona spekulatywną futurologią i obnaża własny utopijny wymiar, jak i z perspektywy literackiej, w której „miękka” psychologia rywalizowała $\mathrm{z}$ „twardą" techniką ${ }^{5}$. Miller, co warto zapamiętać, za początek science fiction przyjmuje twórczość Herberta G. Wellsa, łączącą aspekt

\footnotetext{
3 G. Miller, Science Fiction and Psychology, Liverpool 2020, s. 12. Dalej w tekście oznaczenie stron tej monografii podawane będzie w nawiasach, po skrócie "SFP".

4 W oryginale: "a historian of the so-called "psy disciplines»" [SFP, s. 2].

5 Sytuację komplikuje zakres znaczeniowy angielskiego science, a następnie - tłumaczenie frazy science fiction na język polski jako "fantastyka naukowa”.
} 
naukowo-techniczny $\mathrm{z}$ utopijnym ${ }^{6}$. $\mathrm{Z}$ tego punktu widzenia nauki społeczne i humanistyczne zostają włączone do wyobraźniowego światostwórstwa ${ }^{7}$. Integralność utopii wymusza bowiem podległość, przewidywalną użyteczność nauki i techniki ${ }^{8}$. Na pierwszy plan wysuwane są tutaj akcenty futurologiczne i zaangażowanie społeczne.

Domena science jest wciąż redefiniowana $\mathrm{w}$ nieustannym napięciu konfrontacji z wiedzą o człowieku' ${ }^{9}$. Stawia jednak własne warunki, wyznacza metodologię postępowania poznawczego opartego na eksperymencie i hipotetyczności (rozwijalnych $\mathrm{w}$ fikcję ${ }^{10}$ ), ale także reguły dyskursu wyjaśniającego i promującego to postępowanie. Jest ona oczywiście także wewnętrznie zróżnicowana, a obie dziedziny - naukowa i literacka - wchodzą w obręb science $\mathrm{z}$ zewnątrz, choć $\mathrm{z}$ różnych stron. Psychologia naśladuje metodologię nauk przyrodniczych ${ }^{11}$, a literatura użycza nauce siły i swobody swej twórczej wyobraźni.

Niewątpliwie Miller wyznacza zakres nakładania się obszarów psychologii i science fiction wstecznie, głównie przez przyjęcie odpowiednich założeń dotyczących powstania, istoty i granic literackiej konwencji. Szczególne znaczenie zyskuje określenie momentu jej narodzin. W przypadku psychologii autor za jej początek uznaje uruchomienie pionierskich kursów uniwersyteckich, co wydaje się zasadne, oznacza bowiem wprowadzenie nowej dziedziny

6 Miller powołuje się na koncepcję Andrew Milnera. „Technokapitalizm” na pierwszy plan wysuwa "racjonalność techniczno-naukową" („technoscientific rationality"), ale czyni to spekulatywnie (utopijnie), a często także polemicznie. Źródeł science fiction poszukuje się również w powieści gotyckiej czy oświeceniowych powiastkach. Najbardziej zasadna wydaje się zatem teza o heterogeniczności konwencji.

7 Jak podkreśla Miller, Darko Suvin uznawał istotność tych metodologii humanistycznych, które także opierają się na metodzie naukowej („falsifiable physical or imaginary (thought) experiments" [SFP, s. 4]). Suvin wymienia tu etnologię, antropologię, językoznawstwo - nauki zdominowane przez strukturalizm. Sam zaś Miller na oznaczenie tej „bardziej naukowej” psychologii używa frazy "scientific psychology” [SFP, s. 4]. Za dyrektywę scjentystyczną uznaje się wówczas dominację przyrodoznawstwa i promieniowanie jego metodologii także na nauki społeczne i humanistyczne [W. Strawiński, Odmiany scjentyzmu, „Filozofia Nauki” 1999, nr 1-2, s. 44].

8 "Science fiction was stimulated by the rhetoric and ambition of the human sciences" [G. Miller, Which utopia, whose future?, s. 109].

9 Szczególnie chodzi o relację między natural sciences a social sciences. Zob. np. The Natural Sciences and The Social Sciences, red. B. Cohen, Boston 1994.

${ }^{10}$ H. Baudin, Awatar świata wyobraźni, przeł. B. Okólska, w: Spór o SF, red. R. Handke, L. Jęczmyk, B. Okólska, Poznań 1989, s. 127. Baudin powołuje się na książkę Pierre'a Versins Encyclopedie de l'Utopie des Voyages Extraordinaires et de la Science Fiction, Lausanne 1972.

11 Co do psychologii zob. np. G. Krampen, L.I. Trierweiler, Some unobtrusive indicators of psychology's shift from the humanities and social sciences to the natural sciences, „International Journal of Humanities and Social Sciences" 2016, nr 3. 
badań do właściwej instytucji - akademii. W przypadku konwencji literackiej tak ostrej granicy nie ma, a jeżeli już, to ma ona charakter nomenklaturowy, wyznaczony przez powstanie terminu science fiction.

Jak wynika z konsekwentnej argumentacji Millera, celem psychologii, mimo jej zainteresowania indywidualną ludzką psychiką, jest ostatecznie włączanie człowieka do społeczeństwa, ustalanie norm działania i reagowania ${ }^{12}$. Psychologia ma podwójny punkt odniesienia $-\mathrm{z}$ jednej strony to „przednaukowa" dusza, a z drugiej - socjologiczny wymiar ludzkiej ,jednostki". Na tym skrzyżowaniu perspektyw Miller włącza kontekst literacko-społeczny, czyli utopijność rozumianą nie tyle jako literacki gatunek, ile proces poznawczo-estetyczny. $Z$ perspektywy myślenia utopijnego, doświadczonego już przez dystopię, jest to stopniowanie zaangażowania społecznego, od rozumienia psychiki, przez analizę zachowań, ich przewidywanie, aż po przejęcie nad nimi kontroli. Także nad pojmowaniem fantastyki w książce Millera ciąży przeświadczenie o pierwszoplanowej i integrującej funkcji utopijności ${ }^{13}$, co widać szczególnie w preferowaniu koncepcji Darka Suvina ${ }^{14}$ oraz jego (mniej lub bardziej polemicznych) kontynuatorów, takich jak Istvan Csicsery-Ronay czy Carl Freedman.

Tradycja utopijna wzmacnia także aspekt światostwórczy fikcji fantastycznej. Bohater literacki ukazywany jest w niej na tle spójnego, zazwyczaj wszechstronnego, obrazu społeczeństwa, które z kolei wpisane zostaje w konstrukcję fantastycznej rzeczywistości. Jeśli można mówić o perspektywie "psychologicznej” w fikcji, o mimetycznym obrazie psychiki, to na pierwszy plan wysuwa się wówczas konfrontacja punktu widzenia postaci wiodącej $^{15}$ (jej uspołecznionej percepcji rzeczywistości) z rozwojem fabuły

12 Wielorakość psychologii podważa takie uogólnienia, a jednak - omówienia podstaw psychologii zmierzają zwyczajowo od „nauki o duszy” ku „nauki o zachowaniu”, a nawet ku etyce [zob. R. Stachowski, O psychologii poszukującej swego przedmiotu, "Przegląd Psychologiczny” 2001, nr 1, s. 11-36].

13 Obok przeświadczenia, że obecnie to właśnie w science fiction uzyskuje pełne brzmienie. "Science fiction is now the genre through which utopias and dystopias are most clearly imagined - and its techniques shed light on psychology's ongoing attempts to take charge of 'the future"' [G. Miller, Which Utopia, whose future?, s. 109].

14 Głównym źródłem inspiracji (w mniejszym stopniu podstawą metodologii) jest koncepcja estrangement Darka Suvina. „The non-mimetic fictional reality is not, however, a higher or separated world like that of fantasy, but rather an alternate version of our own reality - past, present, or future" [SFP, s. 2]. Międzyświatowe połączenie zapewnia novum - czynnik modyfikujący, nadający fikcyjnemu światu znamiona fantastyczności. Miller definiuje estrangement słowami Istvana Csicsery-Ronaya: „inducing a perspective of critical displacement from the distorted ideological perception of social reality". Novum musi zajmować centralne miejsce w logice opowieści (,it determines the whole narrative logic" [SFP, s. 3]). Łatwo wskazać novum w prostych narracjach, w rozległych konstrukcjach o strukturze świata - trudniej. 
wykraczającej poza indywidualny los bohatera. Poza fikcją literacką taka sytuacja przyczynia się do narodzin paradygmatów psychologii o nacechowaniu "aktywistycznym” oraz krytycznym. Tak się stało chociażby w przypadku "psychologii feministycznej”, silnie nacechowanej dyskursem utopijnym (w rozumieniu Karla Mannheima) ${ }^{16}$. Najistotniejsza jest jednak obserwacja wynikająca z toku rozumowania autora Science Fiction and Psychology, że wszystkie „wielkie" paradygmaty psychologii swój własny utopijny wymiar posiadają, ponieważ wszystkie mają charakter postulatywny i polemiczny.

Aby sprawnie konfrontować dyskursy, fantastyka naukowa wymaga precyzyjnego konstruowania fikcyjnych światów. Importowanie koncepcji psychologicznych często wchodzi w konflikt właśnie z ontologiczną podstawą konwencji. Dylemat ten najtrafniej sformułował Samuel R. Delany w interpretacji stworzonego ad hoc inicjum powieściowego "Jej świat eksplodował"17. Jak twierdził, w prozie realistycznej, zakładającej podstawę niezróżnicowanego fikcyjnego świata, tak radykalne świadectwa zmiany w rzeczywistości fikcyjnej, jak to reprezentowane przez powyższą frazę, nie są odczytywane dosłownie. $\mathrm{W}$ realistycznym odczytaniu dominuje metaforyczna psychologizacja. W procedurach odbioru charakterystycznych dla science fiction przewage zyskuje natomiast ontologia fantastycznego świata. Tutaj cały świat „rzeczywiście” może eksplodować. Sytuacja ta wprowadza komplikacje przy próbach pogłębiania psychologii postaci. Należy oczywiście zachować ostrożność przy niecodziennych zestawieniach słów i frazeologizmach, ale ciążenie ku światostwórstwu i prymarnej globalizacji (uniwersalizacji) przyrastających w odbiorze znaczeń pociąga za sobą redukcję motywacji wewnętrznych (psychicznych). Zbiór postaci staje się w science fiction "personelem” ${ }^{18}$. Dodatkowo, mieszkańcy fantastycznego świata nie muszą być ludźmi (tj. ich fikcyjnymi odpowiednikami), co z kolei może wywoływać napięcie poznawcze, prowokować porównywanie istot fikcyjnych z zakładanym, mimetologicznym ${ }^{19}$ obrazem człowieka.

15 W narracyjnej technice punktów widzenia.

16 „Feminist psychology has perhaps been most willing to talk frankly about the generation of its research programme within concrete visions for a better future" [G. Miller, Which utopia, whose future?, "The Psychologist” 2020, nr 7-8, s. 111].

17 „Her world exploded” [S. R. Delany, Science Fiction and "Literature” - or, The Conscience of the King, w: tegoż, Starboard Wine, Middletown 2012, s. 68].

18 S. Sanders, Niewidzialni mężczyźni i kobiety: zanik bohatera w science fiction, przeł. E. Petrajtis O’Neill, w: Spór o SF, s. 282-285. Proces „rozpłynięcia się" bohatera w science fiction - warto zaznaczyć - jest równoległy wobec podobnych strategii przyjmowanych przez modernistów i symbolistów [tamże, s. 284].

19 Ze świadomością konwencjonalności realizmu. Por. Z. Mitosek, Ta dziwna mimesis, „Teksty Drugie" 2003, nr 5, s. 82-87. 
Na powyższe dylematy nakłada się, wzmocniona ostatnimi laty, opozycja między stabilizowaniem światów fantastycznych a mnożeniem narracji. Można dostrzec, przy okazji diagnozowania postępującej liczby efektów strategii "trans" (transnarracyjnych, transmedialnych ${ }^{20}$ ), zależność redukcji psychologizacji postaci od koncentracji na światostwórstwie. Natomiast utwory fabułocentryczne, których kompozycja zbudowana jest wokół zdarzeniowości (,story-dominant"), przejawiają tendencję do ujawniania psychologicznych aspektów działania postaci ${ }^{21}$.

Z perspektywy dzisiejszej psychologii literatura piękna w różnym stopniu dotykała i dotyka problematyki badanej w jej ramach. Twórczość literacka zawiera opisy schematów zachowań i próby ich intuicyjnej syntezy. W fantastyce właśnie psychika postaci, choćby schematyczna i powierzchowna, zmienia się względnie najrzadziej. W takim kontekście trudno mówić o potencjalnej „psychologizacji” fikcji fantastycznej ${ }^{22}$.

Z punktu widzenia psychologa interesujące może się natomiast okazać konfrontowanie prywatnych punktów widzenia (indywidualnych światoobrazów) z paradygmatami, światoobrazami kulturowymi. Szczególną wyrazistość napięcie to zyskało właśnie po zdiagnozowaniu roli narracji w psychologii, gdy zestawiane są „małe" i „wielkie" narracje ${ }^{23}$. Wielkim narracjom przypisuje się moc kreacyjną, małe uczestniczą zaś w regulowaniu samorozumienia (uwaga psychologów narracyjnych skierowana jest przede wszystkim na te ostatnie, czyli opowieści autobiograficzne ${ }^{24}$ ). Science fiction umożliwia eksponowanie tej opozycji i polemikę z antropocentryzmem. Może także twórczo wykorzystywać wahania ontyczne, gdy porusza się na granicy szaleństwa i wieloświatów, na przykład w twórczości Philipa K. Dicka.

Wróćmy jednak do kwestii podstawowych. Rozumowanie Gavina Millera wychodzi od doświadczenia codziennej obecności psychologizacji przede wszystkim w autorefleksji człowieka Zachodu („"psychologization» of Western society" [SFP, s. 9]). Jesteśmy bowiem, zdaniem Millera, „podmiotami

20 J.-N. Thon, Converging Worlds. From Transmedial Storyworlds to Transmedial Universes, „Storyworlds: A Journal of Narrative Studies" 2015, nr 2, s. 21-32.

21 M.-L. Ryan, The Aesthetics of Proliferation, w: World-Building. Transmedia, Fans, Industries, red. M. Boni, Amsterdam 2017, s. 36-37, 40.

${ }^{22}$ Choć sam „psychologizm” - w ramach praktyk dyskursywnych krytyki literackiej - traktowany był często jako potencjalne zakłócenie wartości estetycznych, oceniano go więc ambiwalentnie [zob. E. Frąckowiak-Wiegandtowa, Psychologizm - przezwa czy nazwa, "Teksty" 1973, nr 4].

23 M. Straś-Romanowska, Psychologia wobec małych i wielkich narracji, w: Psychologia matych $i$ wielkich narracji, red. M. Straś-Romanowska, B. Bartosz, M. Żurko, Warszawa 2010.

24 Tamże, s. 21. 
działającymi w ramach schematów wyjaśnianych i kształtowanych przez rywalizujące ze sobą psychologiczne metodologie (szkoły)" [SFP, s. 1]. Tymczasem science fiction nie jest kojarzona $\mathrm{z}$ doświadczeniem (naszej) codzienności, wręcz przeciwnie - funkcjonuje jako literacka eksploracja naukowych hipotez. Ta rozbieżność jest jednak sfunkcjonalizowana. Naukowy dyskurs psychologiczny budowany był w naśladującej opozycji wobec uznanych dyskursów naukowych (nauk eksperymentalnych ${ }^{25}$ [SFP, s. 12]), a dziś określa się także dzięki opozycji do nienaukowej parapsychologii. W pewnym stopniu przypomina to sytuację science fiction wyodrębniającej się z literatury imaginacyjnej, opozycyjnej wobec realizmu, nieustannie gotowej do określania się na podwójnej granicy z horrorem i fantasy. Repertuar tematyczny jest szeroki - obejmuje zainteresowanie technikami modyfikacji neurobiologicznych, psychologią, także społeczną, wreszcie - parapsychologią. Polemika z dyskursami zewnętrznymi odzwierciedlała się w przesunięciach wewnątrz konwencji - od "hard" do "soft" science fiction.

W science fiction, jeśli ująć tę konwencję en masse, nad fabularno-historyczną koniecznością dominuje wielorakość rywalizujących koncepcji naukowo-światopoglądowych. Podobnie w psychologii, która sens zyskuje w liczbie mnogiej, jako "psychologie”, nieustannie konfrontowane są paradygmaty łączliwości obrazu "ja" z obrazami „świata". Autor omawianej tu monografii konsekwentnie skupia się na przeglądzie idei i ich "użycia” („use of ideas" [SFP, s. 236]) właśnie w ramach przeglądu tych paradygmatów. Kompozycja monografii Gavina Millera jest więc przewidywalna ze względu na dominację psychologii w porządkowaniu materiału. Naśladuje ona typowy porządek podręczników psychologii wyznaczany przez historię rywalizacji systemów ${ }^{26}$. Jeśli przyjrzymy się ilości miejsca poświęconego poszczególnym szkołom badawczym, okaże się, że żadna z nich nie uzyskała w książce Millera przewagi. Znów zgodnie z przewidywaniami. Na pierwszy rzut oka zaskakujący może być jedynie fakt, że nieco mniej miejsca badacz poświęca psychologii kognitywnej, ale, jak sądzę, to właśnie korzyści płynące z przyjęcia tej perspektywy stanowią ciche założenie całej książki.

W doborze materiału literackiego autor stawia na reprezentatywność i różnorodność („,a diversity of psychological deployments" [SFP, s. 11]). Jeśli zaś chodzi o kategoryzacje konwencji literackich i preferencje z nią związane,

25 Zob. np. R. Stachowski, Początki polskiego czasopiśmiennictwa psychologicznego, „Czasopismo Psychologiczne" 1995, nr 1-2, s. 65.

26 ,"F]or the purposes of this monograph, 'psychology' is defined as the cluster of disciplines" [SFP, s. 12]. Brakuje nadrzędnego paradygmatu, wobec czego psychologia definiowana jest w kategoriach społecznych oraz instytucjonalnych [SFP, s. 16]. 
badacz przyjmuje stanowisko "tymczasowe", gdy decyduje się na utrzymanie różnicy między science fiction a fantasy [SFP, s. 6]. Jak zaznacza, wybór fantastyki naukowej wydaje się bardziej produktywny, pozwala bowiem na określenie warunków wyjściowych dla ewentualnych późniejszych analiz utworów należących do innych konwencji. W science fiction psychologiczny dyskurs pełni bowiem rozmaite funkcje - potrafi (w konsekwencji przyjmowania strategii autotematycznych) wchłaniać „naukowość” psychologii, ale może też wprost ją tematyzować, m.in. dzięki swym dydaktyczno-futurologicznym wariantom. Miller stara się zachować równowagę między samoświadomymi literackimi grami a zaangażowaniem poznawczym literatury. Nie do końca mu się to udaje. Ostatecznie książka jednostronnie akcentuje powagę psychologicznych koncepcji w perspektywie ich społecznego funkcjonowania (,,socially presumed validity of psychological concepts" [SFP, s. 6-7]), w cien usuwając fantastyczne humorystyczne i ironiczne gry.

Przegląd psychologicznych koncepcji obecnych w science fiction Miller zaczyna od psychologii ewolucyjnej. $W$ tym przypadku podkreśla krytykę idealistycznych programów interpretowanych jako utopie. $Z$ tego punktu widzenia „zatrudnienie” psychologii ewolucyjnej w science fiction ma podłoże antyutopijne [SFP, s. 45]. Utopijność zakłada bowiem statyczność, a ewolucja, nieustanna wielowymiarowa zmienność z konieczności wskazuje na pozorność „doskonałych” rozwiązań. Wehikuł czasu Herberta G. Wellsa, zajmujący $\mathrm{w}$ argumentacji Millera miejsce szczególne, zawiera przewrotną wizję ewolucji społeczno-biologicznej, w której tradycyjna utopia okazuje się zdradliwą iluzją [SFP, s. 51]. Otwarcie drapieżna jest z kolei powieść Roberta A. Heinleina The Moon is a Harsh Mistress (1966) ${ }^{27}$.

Ewolucjonizm nie ogranicza się do aspektu biologicznego. Zdominować może także inne wymiary ludzkiego istnienia: społeczny i religijny. Darwinizm, rozwijany przez filozofów takich jak Herbert Spencer, zostawia ślady w myśleniu socjologicznym oraz ekonomicznym. Wydaje się wspierać kapitalistyczny leseferyzm, w konsekwencji - uzasadnia prawo silniejszego w społecznej rywalizacji [SFP, s. 46]. Problematyzując tego typu schematy światopoglądowe fantastyka naukowa tworzy środowisko hiperbolizacji umożliwiające krytykę takiej agonistycznej postawy, Miller przywołuje w tym kontekście powieść Galapagos Kurta Vonneguta (1985) ${ }^{28}$. Podobny sceptycyzm wydaje się w konwencji fantastycznonaukowej zresztą dość powszechny. Szczególnie wyrazistą formę przybrał w Lemowskiej koncepcji

27 R.A. Heinlein, Luna to surowa pani, przeł. P. Znaniecki, Poznań 1992.

28 K. Vonnegut, Galapagos, przeł. D. Józefowicz, Poznań 2020. 
materialistycznej „autoewolucji” człowieka ${ }^{29}$. W szerszym wymiarze wpisuje się w filozofię „mistrzów podejrzeń" we wpływowym ujęciu Paula Ricoeura [SFP, s. 48]. Ostatecznie, granica między psychologią ewolucyjną a psychologią społeczną i socjologią jest wieloraka i deklaratywna. Na nierozwiązywalność i nieredukowalność współzależności podmiotu ewolucji kulturowej i jego uprzedmiotowienia $\mathrm{w}$ koncepcji ewolucjonistycznej wskazywał biolog Stephen Jay Gould: „ludzkość na drodze ewolucji opanowała czytanie i pisanie, ale nie był to efekt adaptacji do środowiska zawierającego teksty" [SFP, s. 50].

Zapewne najlepiej rozpoznawalnym dyskursem psychologicznym jest psychoanaliza - to jej poświęca Miller kolejny rozdział swej monografii. Dyskurs psychoanalityczny pojawia się $\mathrm{w}$ science fiction $\mathrm{w}$ postaci stematyzowanej, jak w powieściach Frederika Pohla Gateway (1987) ${ }^{30}$ oraz Alfreda Bestera The Demolished Man (1953) ${ }^{31}$, zawierających psychoanalityczny żargon podsuwający interpretacyjne wskazówki. Mamy nawet szansę na spotkanie z fantastycznym "dowodem" istnienia nieświadomości w postaci "potwora z Id" w klasycznym filmie Zakazana planeta ${ }^{32}$.

Warto jednak pamiętać, że w literaturze fantastycznonaukowej znajdziemy - obok sprawnie zanalizowanej przez Millera jawnej obecności dyskursu psychoanalitycznego - wiele przykładów odkrywania kulturowych masek, tropienia podświadomych motywacji psychicznych ukrywanych przez pozornie trwałe wzorce społeczne ${ }^{33}$. Dyskurs psychoanalityczny może się wówczas pojawiać na poziomie interpretacji prowokowanej przez symbolikę obecną w fantastycznonaukowych tekstach. Do takich odczytań uprawnia na przykład Solaris Stanisława Lema (1961), powieść, która może być interpretowana jako studium poczucia winy ${ }^{34}$. Trauma nie jest oczywiście zarezerwowana dla psychoanalizy, ale dobrze się w niej odnajduje,

29 Ze szczególną dobitnością zaprojektowana w Podróży dwudziestej pierwszej z Dzienników gwiazdowych (Warszawa 1971). Zob. także J. Jarzębski, Modele ewolucji u Lema, "Postscriptum” 2006, nr 1.

30 F. Pohl, Gateway - brama do gwiazd, przeł. M. Iwińska, P. Paszkiewicz, Warszawa 1987.

31 A. Bester, Człowiek do przeróbki, przeł. A. Sawicki, Warszawa 1994.

32 Forbidden Planet, 1956, reż. F. M. Wilcox, scen. C. Hume.

33 Freud zaliczony został przez Ricoeura w poczet "filozofów podejrzeń" [M. Węgrzyn, Psychoanaliza i kultura. Ricoeurowskie odczytanie Freuda, „Hybris” 2016, nr 2, s. 69-85].

34 Manfred Geier wyodrębnia w dyskursie Solaris, w konstrukcji postaci Kelvina, specyficzne ślady myślenia podszytego nieuświadomionymi pragnieniami [zob. M. Geier, Fantastyczny ocean Stanisława Lema (przyczynek do semantycznej interpretacji powieści Science Fiction "Solaris"), przeł. R. Wojnakowski, w: Lem w oczach krytyki światowej, red. J. Jarzębski, Kraków 1989; zob. także Ł. Kucharczyk, Granice interpretacji. Na przykładzie Solaris Stanistawa Lema, „Spotkania Humanistyczne" 2016, nr 6, s. 44]. 
ze względu na podstawową z założenia rolę doświadczeń negatywnych w kształtowaniu psychiki.

Do popularnych i reprezentatywnych obiektów psychoanalitycznych analiz należy, również pominięta przez Millera, seria filmów Obcy ${ }^{35}$, aktywująca destrukcyjną relację między matką a monstrualnym dzieckiem. Oczywistym kontekstem interpretacyjnym dla szerokiego spektrum topiki superbohatera są z kolei freudowskie "fantazje ratunkowe" (mogą one nabierać konkretnego, utopijnego rysu). Takich motywacji doszukiwano się w serialu Star Trek (pierwszej, "oryginalnej” serii) ${ }^{36}$. Nie sposób zamknąć tego wyliczenia, ale warto jeszcze wspomnieć o często przywoływanym w kontekście topiki podróży w czasie kompleksie Edypa ${ }^{37}$.

Wpływ psychoanalizy na kulturę XX wieku bywa obezwładniający. Fantastyka naukowa nie stanowi tu wyjątku. Wręcz przeciwnie - okazuje się wdzięcznym środowiskiem realizacji fantazji pisarskich oraz interpretacyjnych. Warto zaznaczyć, że spośród psychologicznych orientacji to właśnie psychoanaliza odcisnęła najwyraźniejsze piętno na badaniach krytycznoliterackich ${ }^{38}$, łączyła się często $\mathrm{z}$ badaniami neomarksistowskimi ${ }^{39}$, queer theory czy badaniami feministycznymi. Preferowaną przez fantastykę naukową skalę globalną oraz topikę umysłowości zbiorowej wspomaga „psychologia analityczna" Carla Gustava Junga [SFP, s. 102-110], przemieszczająca badania ukrytych treści psychicznych w stronę archetypowej "semantyki kultury" ${ }^{40}$. Science fiction - na poziomie analizy kulturowego znaczenia konwencji - nabiera wówczas rysów współczesnej „mitologii” ${ }^{41}$.

35 Rozpoczęta filmem Alien, 1979, reż. R. Scott, scen. D. O'Bannon.

36 M.J. Deegan, Sexism in Space: The Freudian Formula in 'Star Trek', w: Eros in the Mind's Eye: Sexuality and the Fantastic in Art and Film, red. D. Palumbo, New York 1986.

37 A.M. Butler, Psychoanalysis, w: The Routledge Companion to Science Fiction, London - New York 2009, s. 292.

38 Spośród szkół badawczych zorientowanych psychologicznie tylko psychoanaliza została wyodrębniona i omówiona w osobnym rozdziale w The Routledge Companion to Science Fiction, London - New York 2009.

39 I. Csicsery-Ronay, jr., Marxist Theory and Science Fiction, w: Cambridge Companion to Science Fiction, Cambridge 2003, s. 116.

40 Z. Mitosek, Teorie badań literackich, Warszawa 2004, s. 196.

41 Symbolicznym łącznikiem, wskazującym na wspólne podłoże nieświadomości zbiorowej, a nie relację przyczynową (nie ma prostego połączenia między obserwacją niezidentyfikowanych obiektów latających a fikcją fantastyczną), jest książka C.G. Junga Nowoczesny mit. O rzeczach, które widuje się na niebie, w: tegoż, Archetypy i symbole. Pisma wybrane, przeł. J. Prokopiuk, s. 248-272. Zob. T.C. Sutton, M. Sutton, Science Fiction as Mythology, „Western Folklore” 1969, nr 4, s. 234. 
Kolejny rozdział poświęca Gavin Miller zbliżeniom science fiction i psychologii behawioralnej. Tutaj dominuje interpretacja utopijno-dystopijna z fantastycznym manifestem Burrhusa F. Skinnera Walden Two (1948) w punkcie wyjścia i na czele [SFP, s. 131-141, 146-149]. Koncepcja człowieka jako mechanizmu reaktywnego kontynuowana była w cybernetyce ${ }^{42}$, także marksistowskiej ${ }^{43}$, poprzez podporządkowanie stabilności i przewidywalności ludzkiego zachowania społecznej homeostazie. Problematyką tą żywo zajął się Stanisław Lem. Cybernetyzacja połączona z wirtualizacją stanie się problemem poznawczo-ontologicznym w prozie Philipa K. Dicka, w której różnica między człowiekiem a androidem ukrywana jest wewnątrz psychiki jako "czarnej skrzynki". Rodzi się wówczas pytanie, czy jest ona istotna, a jeśli tak, to w jakim stopniu. Niestety, twórczość Dicka reprezentowana jest w książce Science Fiction and Psychology w niewielkim stopniu, jedynie przez opowiadanie We Can Remember it For You, Wholesale ${ }^{44}$.

Jako dzieła krytyczne wobec koncepcji behawiorystycznych Miller przywołuje A Clockwork Orange Anthony'ego Burgessa (1962) ${ }^{45}$ oraz The Lathe of Heaven Ursuli K. Le Guin (1971) ${ }^{46}$. Bohater ostatniej z wymienionych powieści poddaje się terapii, gdy uświadamia sobie zdolność modyfikowania rzeczywistości (w wahaniu między solipsyzmem a koncepcją światów alternatywnych). Nie tylko wymiar terapeutyczny okazuje się zatem w kontekście behawioryzmu istotny. Współczesne nurty psychologii „praktycznej”, wykorzystującej narzędzia retoryki i techniki indukowania iluzji poznawczych oraz modyfikacji zachowań, okupują listy bestsellerów ${ }^{47}$. Cel praktyczny pozwala przy tym na powiązanie metodologii behawiorystycznych i kognitywistycznych. Przy okazji psychologii behawioralnej należy zatem przywołać

42 A. Bodanko, O cybernetyce, jej zwiazkach z psychologia i o cybernetycznej koncepcji człowieka, "Nauczyciel i Szkoła” 2013, nr 2.

43 R. Urban, Cybernetyka i nauki humanistyczne w ZSRR, "Conversatoria Linguistica" 2018, s. 258.

44 P.K. Dick, Przypomnimy to panu hurtowo, przeł. B. Jankowiak, w: Droga do Science Fiction 3: od Heinleina do dzisiaj, red. J. Gunn, Warszawa 1987.

45 I zastosowane w niej techniki „prania mózgu”. Behawioryzm akcentuje kontrolowanie zachowań. Brainwashing może być jednak również charakteryzowane przez "przesunięcie” ku kognitywistyce. Polski przekład powieści - A. Burgess, Mechaniczna pomarańcza, przeł. R. Stiller, Warszawa 1991.

46 Por. B.J. Bucknall, Ursula K. Le Guin, New York 1981, s. 90. Polski przekład powieści U. K. Le Guin, Jesteśmy snem, przeł. A. Sylwanowicz, Gdańsk 1991.

47 Szczególnie książki Roberta B. Cialdiniego. Pierwsza z nich to Influence. The Psychology of Persuasion (1984). Polski przekład - R. Cialdini, Wywieranie wpływu na ludzi: teoria i praktyka, przeł. B. Wojciszke, Gdańsk 1995. 
koncepcję konstruktywizmu społecznego (social constructionism), co Miller czyni [SFP, s. 149-164], m.in. na przykładzie roli konstrukcji wariantów płciowości w kreacji fantastycznych światów [SFP, s. 151-158].

Oba paradygmaty: behawioralny i konstruktywistyczny wydają się odpowiadać fantastyce naukowej jako metodzie organizacji wiedzy ze względu na dominację wymiaru społecznego nad jednostkowym i problematyzację tego ostatniego. Dostrzec tu można słabość ostrego podziału i założenia odpowiedniości między paradygmatami psychologii a twórczością fikcjonalną. Ta ostatnia bowiem stosunkowo rzadko zainteresowana jest manifestacją konkretnego stanowiska badawczego. Prawdą wydaje się też, że rzadziej realizuje wariant "psychologizmu".

Zdecydowanie opozycyjna wobec powyższych koncepcji jest psychologia (psychoterapia) humanistyczno-egzystencjalna, w której między psychoterapeutą a pacjentem nawiązuje się relacja osobowa (podobnie jak $\mathrm{w}$ filozofii dialogu ${ }^{48}$ ). Wyróżnia się ona akcentowaniem pozytywnych aspektów ludzkiej egzystencji ${ }^{49}$.

Rozumienie dzieła literackiego nie jako uprzedmiotowienia, lecz otwarcia na dialog, samo w sobie jest atrakcyjne. W obszarze fantastyki naukowej nastawionej na opracowywanie wariantów przyszłości takiego nastawienia można by się dopatrywać w koncepcji „poszerzonej teraźniejszości”, w której etyka odpowiedzialności przezwyciężyłaby pozory futurologii ${ }^{50}$. Rozważania Gavina Millera zmierzają jednak w innym kierunku. Perspektywa humanistyczno-egzystencjalna $\mathrm{w}$ jego interpretacji oznacza aktywację bezpośredniego mimetycznego charakteru fantastyki naukowej, w jej aspektach dydaktycznych i właśnie profetycznych [SFP, s. 179-183] ${ }^{51}$. Tak interpretuje Miller powieść Doris Lessing The Four-Gated City (1969), w której podłoże autobiograficzne rozwijane jest w kierunku reintegracji fikcyjnej osobowości. Reintegracja ta dokonuje się w obliczu fikcyjnych katastrof cywilizacyjnych, a właściwie - dzięki nim. Koncentracja na rozwoju osoby powoduje, że po-

48 G. Krupa, Psychoterapia humanistyczno-egzystencjalna w świetle filozofii spotkania, w: Etyka pracy socjalnej w filozofii spotkania i dialogu, red. M. Duda, I. Rybka, H. Kaszyński, Kraków 2017.

49 A.A. Płatonow, Szczęście i zadowolenie z życia (psychologia pozytywna), Warszawa 2015, s. 7-9. „Psychologia pozytywna” to wiązka tendencji, które pojawiają się wewnątrz różnych metodologii - por. The Oxford Handbook of Positive Psychology, red. S.J. Lopez, C.R. Snyder, Oxford 2009.

50 „Poszerzona teraźniejszość” rozumiana jako wzmocnienie samoświadomości poprzez sprzężenie aktywnego pamiętania z projektowaniem przyszłości („die breite Gegenwart”) [zob. H. U. Gumbrecht, Our Broad Present: Time and Contemporary Culture, New York 2014, s. XIII].

51 "Czy psychologia pozytywna to utopia?" - pyta w tytule rozdziału swej monografii Ewa Trzebińska [E. Trzebińska, Psychologia pozytywna, Warszawa 2008, s. 182-184]. 
wieść Lessing nie funkcjonuje jako w pełni konwencjonalna proza („is poised between 'serious' and 'genre' writing" [SFP, s. 186]). W trakcie samorealizacji (w duchu psychologii Abrahama Maslowa ${ }^{52}$ ) jej główna bohaterka przekracza granicę wyobcowania $\mathrm{z}$ własnego społeczeństwa. Przewagę $\mathrm{w}$ tym rozdziale zyskuje proza kobieca, utwory takich pisarek jak Naomi Mitchison (Memoirs of a Spacewoman, 1962) oraz Marge Piercy (Woman on the Edge of Time, 1976). Egzystencja traktowana jest w nich jako przetrwanie ,ja" w sytuacji rozdarcia (z powodu współistnienia sprzecznych wartości).

Psychologia humanistyczna jest z pewnością - warto dodać w kontekście rozważań Gavina Millera - otwarta na refleksję nad granicami człowieczeństwa $\mathrm{w}$ obliczu transhumanistycznych modyfikacji. W ramach science fiction na konieczność zachowania czujności wskazuje chociażby głośna dystopia Davida Eggersa The Circle (2013), nie uciekająca od "rozrywkowej” konwencjonalności ${ }^{53}$. Perspektywa ta jest szczególnie istotna w obliczu udziału dyskursu fantastycznonaukowego w pracach definiujących kulturową, "teoretyczną" samoświadomość - Jeana Baudrillarda czy Donny Haraway ${ }^{54}$. Z kolei doświadczenia graniczne zbliżają psychologię egzystencjalną, szczególnie Karla Jaspersa, i fantastycznonaukową grozę ${ }^{55}$. W aspekcie pozytywnym ujawnia się wówczas, jako wartość, potrzeba ładu i bezpieczeństwa umieszczana przez Maslowa blisko podstawy hierarchii wartości. Przynależność do wspólnoty, jako jeden ze sposobów realizacji tej potrzeby, ujawnia się w strukturach fabularno-emocjonalnych horroru ${ }^{56}$ (także fantastycznonaukowego). Pozytywność określana jest jednak wciąż dzięki zainteresowaniu patologicznymi zjawiskami psychicznymi ${ }^{57}$. W tych konwencjach fikcjonalny lęk pociąga za sobą korekty poznawcze, które mogą zdecydować o ontologii fikcyjnych światów.

52 A.H. Maslow, Motywacja i osobowość, przeł. J. Radzicki, Warszawa 2009, s. 62-76.

53 Polskie wydanie D. Eggers, Krag, przeł. M. Fedyszak, Katowice 2015. Por. T.W. Galow, Understanding Dave Eggers, Columbia 2014, s. 126.

54 I. Csicsery-Ronay, jr., The SF of Theory: Baudrillard and Haraway, "Science Fiction Studies" 1991, nr 3.

55 Groza ma wówczas pouczający walor. W arcyciekawej, z uwagi na fabułotwórczą funkcję aluzji, powieści Franka Herberta The Santaroga Barrier (1968) poszerzająca świadomość substancja psychoaktywna o nazwie Jaspers wykazuje zdolność modyfikowania rzeczywistości za pośrednictwem zbiorowego umysłu.

56 N. Carroll, Filozofia horroru albo Paradoksy serca, przeł. M. Przylipiak, Gdańsk 2004, s. 168-216. Fabularną fazę „,konfrontacji” w strukturze horroru poprzedza zazwyczaj faza „potwierdzania", czyli trudnego budowania koalicji w celu pokonania potwora.

57 Kategoryzacje te zawdzięczamy w dużej mierze romantycznemu etapowi rozwoju fantastyki. A. Kowalczykowa, Romantyczni szaleńcy, Warszawa 1977. 
Przegląd koncepcji psychologicznych importowanych $\mathrm{w}$ fantastyce naukowej kończy Miller na psychologii poznawczej (kognitywnej), badającej procesy i reprezentacje mentalne, schematyczne i społecznie motywowane. Nietrudno dostrzec, że jesteśmy obecnie niemalże bombardowani rewelacjami na temat podatności naszych umysłów na konformistyczne iluzje poznawcze ${ }^{58}$. Chęć współpracy społecznej płynnie przechodzi w łatwość podporządkowania się ${ }^{59}$ i taka diagnoza dobrze rzecz jasna współbrzmi z fantastyczną tonacją dystopijną. Uniwersalny charakter podobnych obserwacji powoduje, że trudno doszukiwać się wyjątkowości wpływu kognitywnej koncepcji psychologicznej na jakąkolwiek literaturę, ale to właśnie w tym rozdziale, poniekąd skazanym na oczywistość, mamy szansę przeczytać najciekawszą chyba w całej książce analizę utworu literackiego - The Body Snatchers (1954) Jacka Finneya ${ }^{60}$. Miller intrygująco definiuje tę powieść jako zamaskowaną demonstrację dyskursu protokognitywistycznego [SFP, s. 207].

Szczególne miejsce w fantastyce "kognitywnej” zajmuje topika neuroinżynierii melioracyjnej demonstrująca powiązania zmian mentalnych i behawioralnych. Miller przywołuje Kwiaty dla Algernona Daniela Keyesa (Flowers for Algernon, 1959 - nowela ${ }^{61}, 1966$ - powieść) oraz Obóz koncentracji Thomasa M. Discha (Camp Concentration, 1967) ${ }^{62}$. W latach 80. XX wieku wątki te obecne będą w subkonwencji cyberpunku [SFP, s. 14].

$\mathrm{W}$ „miękkim” wariancie ingerencje cielesne zastępuje manipulacja środowiskiem semiotycznym, głównie językowym. Język sztuczny może się nawet okazać znakomitą bronią, jak w Babel-17 Samuela R. Delany'ego (1966) ${ }^{63}$. Język Obcych potrafi modyfikować świadomość i wpływać na ludzkie linearne postrzeganie rzeczywistości. Ten wariant fabularny znajdziemy $\mathrm{w}$ noweli Teda Chianga Historia twojego życia (Story of Your Life, 1998) ${ }^{64}$. Język może tworzyć iluzję, ale może też ustanawiać rzeczywistość. Zakłóca rozróżnienie tych jakości bądź je zrównuje. Zawsze jednak problematyzuje towarzyszące

\footnotetext{
58 "Human mind typically operates as a biased, limited capacity information processor" [SFP, s. 207].

59 Dowodem tej tezy miał być słynny „eksperyment Milgrama” [zob. S. Milgram, Posłuszeństwo wobec autorytetu, przeł. M. Hołda, Kraków 2008].

60 Powieść została kilkakrotnie zekranizowana. Pierwszy z filmów - Invasion of the Body Snatchers (1956, reż. D. Siegel) - pozostaje najbardziej znany.

61 Polski przekład - D. Keyes, Kwiaty dla Algernona, przeł. K. Malinowski, w: Droga do Science Fiction: od dzisiaj do wieczności, red. J. Gunn, Warszawa 1988.

62 T.M. Disch, Obóz koncentracji, przeł. D. Kopociński, Stawiguda 2008.

63 S.R. Delany, Babel-17, przeł. J. Pers, Stawiguda 2008.

64 T. Chiang, Historia twojego życia, przeł. M. Jakuszewski, w: tegoż, Historia twojego życia, Poznań 2016.
} 
temu procesy psychiczne: zaangażowanie $\mathrm{w}$ tworzenie światów ${ }^{65}$ oraz emocjonalne „zanurzanie się" w nich - immersję ${ }^{66}$. Obcowanie z fikcją pozwala na ujawnienie się kreacyjnego (fikcjonalnego) wymiaru wiedzy, czyli „efektu tekstowego" niezależnego od zewnętrznych kryteriów [SFP, s. 5-6].

Książkę Gavina Millera zamykają, skromniejsze ilościowo, rozważania o zależności "odwrotnej”, to jest o obecności fantastyki naukowej w dyskursie psychologicznym. Z punktu widzenia badacza konwencji literackiej są to fragmenty szczególnie interesujące. Jak wyznał Miller, mimo pokusy wypełnienia tego rozdziału (a nawet całej monografii) zbiorowym portretem (prosopography) pisarzy-psychologów, takie prostolinijne nastawienie zostawiłoby na marginesie to, co najciekawsze. Zbyt często okazuje się bowiem, że właśnie pisarze nieposiadający akademickiego przygotowania $\mathrm{w}$ tym zakresie tworzyli najbardziej zajmujące interpretacyjnie utwory [SFP, s. 9].

Jak słusznie wskazuje Miller, rozróżnienie kierunków oddziaływania między psychologią a fikcją fantastycznonaukową ma charakter głównie analityczny. Nadrzędna okazuje się bowiem narracyjna wyobraźnia utopijna - „utopian and dystopian storytelling" 67. Wyobraźnia utopijna ujawnia się wszędzie tam, gdzie - także psychologia akademicka - próbuje tworzyć obrazy przyszłości o ambicjach futurologicznych [SFP, s. 250]. Badania nad światostwórstwem wymagają nastawienia interdyscyplinarnego.

Literatura piękna i psychologia wchodzą $\mathrm{w}$ wielowymiarowe zależności, począwszy od procesu twórczego, skończywszy na zainteresowaniu pisarzy psychologią i psychologów fikcją literacką. Istotą tej zależności jest operatywność dyskursu psychologicznego, czyli zdolność do wyjaśniania i funkcjonalizacji psychicznych zjawisk przez naukowców, co w praktyce oznacza interakcje między dyskursami: psychologicznym i krytycznoliterackim. Trzeba mieć jednak świadomość, że to próba racjonalizacji żywiołu uchwytnego intuicyjnie ${ }^{68}$, w którym twórczość, wyobraźnia, emocje i rozum są nierozdzielne.

65 Szczególnie w akcentowaniu udziału światostwórstwa w dziecięcych zabawach oraz ogólniej - w ludycznych formach aktywności [zob. M.J.P. Wolf, Building Imaginary Worlds: The Theory and History of Subcreation, New York 2012, s. 3-6].

66 Zob. np. R. Gerrig, Experiencing Narrative Worlds: On the Psychological Activities of Reading, New Haven 1993.

67 "The reality is far more complex: both psychology and science fiction engage in utopian and dystopian storytelling, and the validity of the science may be questionable (clearly so in science fiction - and even in psychology)" [G. Miller, Which utopia, whose future?, s. 111].

68 Podobną tezę sformułował Paul Valéry: „Celem psychologii jest przedstawienie zupełnie innego wyobrażenia o tym, co wiemy najlepiej” („L'objet de la psychologie est de nous donner une idée toute autre des choses que nous connaissons le mieux") [P. Valéry, Tel quel, Paris 1944, s. 279]. 
Przynosi ona wiedzę o ludzkiej psychice, którą moglibyśmy, z dzisiejszej perspektywy psychologicznej, nazwać wiedzą przednaukową. Z pewnością psychologia społeczna - by sięgnąć po spektakularny przykład - uzyskała nowe dane dzięki sile oddziaływania Wojny światów Herberta G. Wellsa ${ }^{69}$. Trudno także odmówić siły wyrazu chociażby amerykańskiej fantastyce paranoidalnej lat 50. czy polskiej fantastyce "socjologicznej” lat 80. ubiegłego wieku. Właśnie paranoja, a raczej „paranoidalność”, znakomicie odzwierciedla istotę fantastycznonaukowego racjonalizmu sytuującego się na granicy społecznej akceptowalności ${ }^{70}$.

W tym kontekście szczególnie interesujące byłoby obszerniejsze określenie sposobów obecności wątków „parapsychologicznych” w science fiction. Wprawdzie Miller wiele miejsca poświęca omówieniu przyczyn rezygnacji $\mathrm{z}$ ich analizy w swej monografiii ${ }^{71}$, ale ta zapobiegliwość nie usuwa uczucia niedosytu. Fantastyka naukowa wydaje się bowiem szczególnie predysponowana do problematyzowania oczywistych - jak by się wydawało - granic między nauką a nienauką ${ }^{72}$.

\section{Bibliografia}

Baudin Henri (1989), Awatar świata wyobraźni, przeł. B. Okólska, w: Spór o SF, red. R. Handke, L. Jęczmyk, B. Okólska, Poznań: Wydawnictwo Poznańskie, s. $123-130$.

Bester Alfred (1994), Człowiek do przeróbki, przeł. A. Sawicki, Warszawa: Amber.

Bodanko Anatol (2013), O cybernetyce, jej zwiazkach z psychologia i o cybernetycznej koncepcji człowieka, „Nauczyciel i Szkoła”, nr 2, s. 213-229.

Broderick Damien (2018), Psience Fiction: The Paranormal in Science Fiction Literature, Jefferson: McFarland.

Bucknall Barbara J. (1981), Ursula K. Le Guin, New York: Ungar.

69 H. Cantril, The Invasion from Mars: A Study in the Psychology of Panic, Princeton 1940.

70 Paranoia Within Reason: A Casebook on Conspiracy as Explanation, red. G.E. Marcus, Chicago 1999. Problem ten poruszyłem w: M.M. Leś, Fantastyka socjologiczna. Poetyka i myślenie utopijne, Białystok 2008, s. 188-196.

71 Miller poświęca im nieco miejsca przy okazji omawiania paradygmatu psychologii humanistyczno-egzystencjalnej. W polu zainteresowania umieścił jednak przede wszystkim psychologię akademicką („,academically authorized psychological discourses” [SFP, s. 20]), usunął więc zeń także niezwykle istotne wątki twórczości Isaaca Asimova: „psychohistorię” oraz „robopsychologię", a przede wszystkim - „dianetykę" L. Rona Hubbarda [SFP, s. 20].

72 Miller jednak docenia pionierską monografię Damiena Brodericka Psience Fiction: The Paranormal in Science Fiction Literature (Jefferson 2018). Cytuje też polemikę Csicsery-Ronaya z Suvinem, który zdecydowanie promował racjonalizm konstrukcji novum w science fiction [SFP, s. 5]. 
Burgess Anthony (1991), Mechaniczna pomarańcza, przeł. R. Stiller, Warszawa: Wydawnictwo WEMA.

Butler Andrew M. (2009), Psychoanalysis, w: The Routledge Companion to Science Fiction, London - New York: Routledge, s. 288-297.

Cantril Hadley (1940), The Invasion from Mars: A Study in the Psychology of Panic, Princeton: Routledge.

Carroll Noël (2004), Filozofia horroru albo Paradoksy serca, przeł. M. Przylipiak, Gdańsk: Słowo/Obraz Terytoria.

Chiang Ted (2016), Historia twojego życia, przeł. M. Jakuszewski, Poznań: Zysk i S-ka.

Cialdini Robert (1995), Wywieranie wptywu na ludzi: teoria i praktyka, przeł. B. Wojciszke, Gdańsk: Gdańskie Wydawnictwo Psychologiczne.

Cramer Kathryn (2003), Hard SF, w: The Cambridge Companion to Science Fiction, red. E. James, F. Mendlesohn, Cambridge: Cambridge UP, s. 186-196.

Csicsery-Ronay Istvan, jr. (1991), The SF of Theory: Baudrillard and Haraway, "Science Fiction Studies", nr 3, s. 387-404.

Csicsery-Ronay Istvan, jr. (2003), Marxist Theory and Science Fiction, w: Cambridge Companion to Science Fiction, Cambridge: Cambridge UP.

Deegan Mary Jo (1986), Sexism in Space: The Freudian Formula in 'Star Trek', w: Eros in the Mind's Eye: Sexuality and the Fantastic in Art and Film, red. D. Palumbo, New York: Greenwood Press, s. 209-224.

Delany Samuel R. (2008), Babel-17, przeł. J. Pers, Stawiguda: Solaris.

Delany Samuel R. (2012), Science Fiction and "Literature" - or, The Conscience of the King, w: S.R. Delany, Starboard Wine, Middletown: Wesleyan UP.

Disch Thomas M. (2008), Obóz koncentracji, przeł. D. Kopociński, Stawiguda: Solaris. Eggers Dave (2015), Krag, przeł. M. Fedyszak, Katowice: Wydawnictwo Sonia Draga. Frąckowiak-Wiegandtowa Ewa (1973), Psychologizm - przezwa czy nazwa, "Teksty", nr 4, s. 193-200.

Galow Timothy W. (2014), Understanding Dave Eggers, Columbia: University of South Carolina Press.

Geier Manfred (1989), Fantastyczny ocean Stanisława Lema (przyczynek do semantycznej interpretacji powieści Science Fiction „Solaris”), przeł. R. Wojnakowski, w: Lem w oczach krytyki światowej, red. J. Jarzębski, Kraków: Wydawnictwo Literackie, s. $142-217$.

Gerrig Richard J. (1993), Experiencing Narrative Worlds: On the Psychological Activities of Reading, New Haven: Yale UP.

Gumbrecht Hans U. (2014), Our Broad Present: Time and Contemporary Culture, New York: Columbia UP.

Heinlein Robert A. (1992), Luna to surowa pani, przeł. P. Znaniecki, Poznań: Rebis.

Jarzębski Jerzy (2006), Modele ewolucji u Lema, „Postscriptum”, nr 1, s. 55-66.

Jung Carl Gustaw (1993), Nowoczesny mit. O rzeczach, które widuje się na niebie, w: C.G. Jung, Archetypy i symbole. Pisma wybrane, przeł. J. Prokopiuk, Warszawa: Czytelnik, s. 248-273.

Keyes Daniel (1988), Kwiaty dla Algernona, przeł. K. Malinowski, w: Droga do Science Fiction: od dzisiaj do wieczności, red. J. Gunn, Warszawa: Wydawnictwo Alfa, s. 73-98. 
Kowalczykowa Alina (1977), Romantyczni szaleńcy, Warszawa: PWN.

Krampen Günter, Trierweiler Lisa I. (2016), Some unobtrusive indicators of psychology's shift from the humanities and social sciences to the natural sciences, "International Journal of Humanities and Social Sciences", nr 3, s. 44-66.

Krupa Grzegorz (2017), Psychoterapia humanistyczno-egzystencjalna w świetle filozofii spotkania, w: Etyka pracy socjalnej w filozofii spotkania i dialogu, red. M. Duda, I. Rybka, H. Kaszyński, Kraków: Uniwersytet Papieski Jana Pawła II, s. 53-70.

Kucharczyk Łukasz (2016), Granice interpretacji. Na przykładzie Solaris Stanisława Lema, „Spotkania Humanistyczne", nr 6, s. 39-52.

Le Guin Ursula K. (1991), Jesteśmy snem, przeł. A. Sylwanowicz, Gdańsk: Phantom Press.

Lem Stanisław (1971), Dzienniki gwiazdowe, Warszawa: Wydawnictwo Czytelnik.

Leś Mariusz M. (2008), Fantastyka socjologiczna. Poetyka i myślenie utopijne, Białystok: Wydawnictwo Uniwersytetu w Białymstoku.

Lopez Shane J., Snyder C.R. [red.] (2009), The Oxford Handbook of Positive Psychology, Oxford: Oxford UP.

Marcus George E. [red.] (1999), Paranoia Within Reason: A Casebook on Conspiracy as Explanation, Chicago: University of Chicago Press.

Maslow Abraham H. (2009), Motywacja i osobowość, przeł. J. Radzicki, Warszawa: PWN.

Milgram Stanley (2008), Posłuszeństwo wobec autorytetu, przeł. M. Hołda, Kraków: WAM.

Miller Gavin (2020), Science Fiction and Psychology, Liverpool: Liverpool UP.

Miller Gavin (2020), Which utopia, whose future?, "The Psychologist", nr 7-8, s. 109-111.

Mitosek Zofia (2003), Ta dziwna mimesis, „Teksty Drugie”, nr 5, s. 82-87.

Mitosek Zofia (2004), Teorie badań literackich, Warszawa: PWN.

Niewiadowski Andrzej, Smuszkiewicz Antoni (1990), Leksykon polskiej literatury fantastycznonaukowej, Poznań: Wydawnictwo Poznańskie.

Płatonow Anatolij (2015), Szczęście i zadowolenie z życia (psychologia pozytywna), Warszawa: Wydawnictwo Politechniki Warszawskiej.

Pohl Frederik (1987), Gateway - brama do gwiazd, przeł. M. Iwińska, P. Paszkiewicz, Warszawa: Wydawnictwo Alfa.

Ryan Marie-Laure (2017), The Aesthetics of Proliferation, w: World-Building. Transmedia, Fans, Industries, red. M. Boni, Amsterdam: Amsterdam UP, s. 31-46.

Sanders Scott (1989), Niewidzialni mężczyźni i kobiety: zanik bohatera w science fiction, przeł. E. Petrajtis O’Neill, w: Spór o SF, red. R. Handke, L. Jęczmyk, B. Okólska, Poznań: Wydawnictwo Poznańskie, s. 282-302.

Stachowski Ryszard (1995), Początki polskiego czasopiśmiennictwa psychologicznego, „Czasopismo Psychologiczne” 1995, nr 1-2, s. 65-78.

Stachowski Ryszard (2001), O psychologii poszukującej swego przedmiotu, „Przegląd Psychologiczny", nr 1, s. 11-36.

Straś-Romanowska Maria (2010), Psychologia wobec małych i wielkich narracji, w: Psychologia małych i wielkich narracji, red. M. Straś-Romanowska, B. Bartosz, M. Żurko, Warszawa: Eneteia, s. 21-40.

Strawiński Witold (1999), Odmiany scjentyzmu, „Filozofia Nauki”, nr 1-2, s. 43-50. 
Sutton Thomas C., Sutton Marilyn (1969), Science Fiction as Mythology, „Western Folklore", nr 4, s. 230-237.

Thon Jan-Noel (2015), Converging Worlds. From Transmedial Storyworlds to Transmedial Universes, „Storyworlds: A Journal of Narrative Studies”, nr 2, s. 21-53.

Trzebińska Ewa (2008), Psychologia pozytywna, Warszawa: Wydawnictwo Akademickie i Profesjonalne.

Urban Roman (2018), Cybernetyka i nauki humanistyczne w ZSRR, "Conversatoria Linguistica", s. 257-270.

Valéry Paul (1944), Tel quel, Paris: Gallimard.

Versins Pierre (1972), Encyclopedie de l'Utopie des Voyages Extraordinaires et de la Science-Fiction, Lausanne : L'âge d'homme.

Vonnegut Kurt (2020), Galapagos, przeł. D. Józefowicz, Poznań: Wydawnictwo Zysk i S-ka.

Węgrzyn Marta (2016), Psychoanaliza i kultura. Ricoeurowskie odczytanie Freuda, „Hybris", nr 2, s. 69-85.

Wolf Mark J. P. (2012), Building Imaginary Worlds: The Theory and History of Subcreation, New York: Routledge.

\title{
Stereotypes and Fantasies: Science Fiction and Psychology
}

\begin{abstract}
The article presents a critical analysis of a monograph by Gavin Miller, Science Fiction and Psychology (2020), and offers a subjective reading of the book. The author of the article believes that Miller's book presents an inspirational and thorough reading of the classical and contemporary science fiction which revises the interaction between two spheres of human activity, cultural and scientific. By analyzing the presence of utopian thinking which provides the groundwork for Miller's considerations, the author notes that the scholar places great emphasis on scientific discourse and methodology.
\end{abstract}

Keywords: science fiction, psychology, utopia, scientific discourse in literature 